\title{
A Library Committee on Diversity and Its Role in a Library Diversity Program
} Kristin H. Gerhard and Jeanne M. K. Boydston

\begin{abstract}
The library profession has been committed to affirmative action, yet it has been historically difficult to convert that philosophical commitment into activity. Academic libraries have paid uneven attention to affirmative action programs over time. This paper examines the historical role affirmative action programs have played in academic libraries, and the shift in focus in recent years from affirmative action to more broadly based diversity programs. It then describes the contribution a library staff may make to these programs by examining the evolution and function of Iowa State University Library's Committee on Diversity.
\end{abstract}

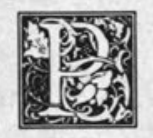

rograms that deliberately seek to increase diversity have a particular importance for libraries within colleges and universities. At a conference on the multicultural library, John F. Noonan, president of Bloomfield College in Bloomfield, New Jersey, describes libraries as "a mirror of society as well as an image in front of the mirror."1 Some students have direct contact with a minority professor, but women, racial minorities, and the disabled working in libraries have higher visibility for the general undergraduate population than do their counterparts in classrooms. In this position "in front of the mirror," these librarians have a unique opportunity to serve as role models, and as a clear demonstration of their institution's commitment to diversity. Affirmative action programs within libraries, then, may well affect colleges and universities.

Librarianship has been committed to affirmative action, yet it has been historically difficult to convert that philosophical commitment into activity. This article examines the role affirmative action programs have played in academic libraries over time and the shift in focus in recent years from affirmative action to more broadly based diversity programs. It then describes the contribution a group of library staff may make to these programs by examining the evolution and function of Iowa State University Library's Committee on Diversity.

Throughout this paper, the authors use the terms affirmative action, diversity, and multiculturalism. Affirmative action programs seek to increase the number of qualified women, minority, and disabled individuals, as well as disabled or Vietnam era veterans hired by an institution. These programs have been the traditional means for achieving diversity, which the authors understand as the representation of, recognition of, and support for more than one kind of life experience within the university. Multiculturalism refers to one specific aspect of diversity: the representation of, recognition of, and support for more than one culture within the institution.

\section{FROM AFFIRMATIVE ACTION TO DIVERSITY PROGRAMS}

In 1978, Elizabeth Dickinson and Margaret Myers investigated affirmative

Kristin H. Gerhard is Assistant Professor and Monographic Cataloger, and Jeanne M. K. Boydston is Assistant Professor and Serials Cataloger, Iowa State University, Ames, Iowa 50011-2140. 
action and American librarianship. When they asked survey respondents to provide a prognosis for affirmative action in librarianship, "answers ranged from cynical to relatively optimistic...."2 Their evaluation of trend data gave a similarly ambivalent picture for the future of affirmative action. They pointed to the growth of minority and women's professional groups, "greater activity in the area of women and ethnic studies and the burgeoning of affirmative action literature" as indicators of raised consciousness regarding affirmative action. ${ }^{3}$ The authors believed these subjective gains would take time before they had objective effect and registered as economic gains. They concluded that affirmative action programs in libraries would grow modestly and would take time to do so.

Twelve years later, Cliff Glaviano and R. Errol Lam suggested that the cynics may have been right. They wrote that affirmative action has not been a primary goal of the library profession since the early 1980s, and that now is the time to reorient the profession. They state:

[while] it is not the primary function of academic libraries to define the multiethnic society or the methodologies the university might employ to educate for the pluralistic society, the libraries can be very influential in establishing and demonstrating a pluralistic environment from which the information needs of all campus cultures might be serviced. ${ }^{4}$

A number of strategies are outlined that libraries may use in promoting this environment. Ideas from the business community include provision of crosscultural training for all company employees, with the intention of improving communication and increasing sensitivity to differences. The authors also note particular support given to minority employees, wherein they "are given instruction in corporate values and behavioral norms of the organization to which they have been recruited." 5

Other ways to promote a multiethnic society are creating displays, building collections in multicultural areas, and improving the diversity of library staff and services that support the library. ${ }^{6}$ Large budgets are not necessary for these programs to succeed. In creating such an effort within the library, Glaviano and Lam suggest that librarians draw on methods that have worked in dealing with other library issues, including networking and activism.

This kind of change requires work. As the authors note, academic libraries in predominantly white institutions are part of the larger institutions they serve. Attitudes held in the library probably reflect attitudes held in the wider university. Staff may not feel that they are responsible for addressing racial diversity on campus. Glaviano and Lam conclude: changes in practice that move the profession toward real improvement in affirmative action will probably originate with underfunded individuals or small groups in local academic libraries.?

The Association of College and Research Libraries (ACRL) Task Force on Recruitment of Underrepresented Minorities issued its final report, Recruiting the Underrepresented to Academic Libraries, in November 1990. The opening lines of the report's introduction highlight the need to refocus library efforts in this area: "Attention to the recruitment and advancement and retention of underrepresented groups in libraries is an idea whose time has come-again!"8 The report notes the waning of this kind of recruitment in the 1980 s and a lack of attention to retention or advancement. The report identifies three targets for change: institutional commitment to change and accountability, personal and institutional racism barriers, and barriers to advancement and retention. It recommends sixteen specific actions ACRL can take.

In response to the task force's report, the ACRL Executive Committee adopted a resolution on cultural diversity in libraries. The resolution states that ACRL is "committed to fostering equality and promoting diversity within the library profession as a whole and specifically within academic libraries." 9 The committee also voted to establish an ACRL Standing Committee on Racial and Ethnic Diversity. The committee's charge is to: 
initiate, advise and mobilize support for appropriate action related to issues of racial and ethnic diversity in academic librarianship including the recruitment, advancement and retention of underrepresented groups to academic librarianship; and the promotion of quality academic library and information services for members of racial and ethnic groups. ${ }^{10}$

Increased focus on diversity issues within ACRL is further evidenced by College \& Research Libraries News' recent inauguration of a regular column called "Racial and Ethnic Diversity: Information Exchange."

In 1990, the Association of Research Libraries (ARL) published a number of documents dealing with affirmative action and diversity topics. They included flyers on affirmative action policies, minority recruitment and retention, and cultural diversity programs. The introductions of these flyers summarize the results of surveys of ARL member libraries' programs in these areas.

The introduction to the affirmative action flyer suggests a significant shift in emphasis in recent years, noting that "affirmative action goals are already moving from being a separate agenda to joining the agenda for diversity."11 This recent shift in emphasis is further illustrated by the documents contained in the flyer on cultural diversity. The introduction to this flyer speaks of business' new valuation of diversity, noting that "demographic changes occurring during the next ten years are expected to affect businesses more than any other development, including technology. America's businesses are allocating significant resources to multicultural awareness training. ${ }^{\prime 12}$ Responses to the cultural diversity programs survey indicated a wide variance among ARL libraries. Some have no diversity programming at all, while others have well-established, comprehensive programs.

The cultural diversity flyer also addresses some barriers to creating these programs. Building strong programs requires a good understanding of diversity issues, an overall strategy, support from all levels of the organization, and the ability to deal with funding limitations. Finally, "librarians working in this area must recognize that support for diversity programs is not universal. ... conflicting views must be acknowledged and debated."13 A recent article by Patrick A. Hall in American Libraries addresses one such viewpoint. ${ }^{14}$

Roberto G. Trujillo and David C. Weber encourage academic libraries to work proactively on cultural diversity issues. They suggest that librarians turn their attention "beyond simple access for minorities to the more difficult issues of participation and collaboration."15 They outline a number of actions libraries can take, but emphasize the importance of maintaining a vision of an environment where all individuals are valued and "where full participation and partnership are the norm."16 They believe that all academic librarians should work to move their libraries toward the realization of that vision:

We all share a responsibility to improve those library conditions that today we deplore. As our profession develops over the decade ahead, ethnic and racial minority groups must be brought into full partnership-they must be valued both for their professional expertise and for the exceptional personal qualities they bring to their work and their profession. ${ }^{17}$

\section{DIVERSITY AND ACADEMIC LIBRARIES TODAY}

The recent rise of interest in diversity is further evidenced by a number of conferences emphasizing this topic. For instance, a 1991 preconference sponsored by ACRL's Bibliographic Instruction Section addressed bibliographic instruction in a multicultural environment. The forum on the multicultural library, held at Bloomfield College in 1990 and mentioned above, is one of many such meetings held locally or regionally in the past year. A recent presentation at an ALA poster session received more than fifty requests for further information. In order to understand the present state of affirmative action and cultural diversity 
programming, librarians need to look at current programs in academic libraries.

Affirmative action programs are an important component of the larger diversity effort. Who is responsible for affirmative action today in hiring for academic libraries? Since the search process is the door through which more diverse librarians must come, it is an important gateway to examine. Jeanne M. K. Boydston surveyed ARL libraries in the United States to examine their hiring practices in regard to equal employment opportunity and affirmative action. She found that all respondents had some university-level unit dealing with equal opportunity and affirmative action on campus. Still, more than half the respondents had a second agency or individual within their library with responsibility for equal employment opportunity and affirmative action. ${ }^{18}$ The entity with this responsibility was either an affirmative action officer or an affirmative action committee.

As academic libraries have worked to build environments more supportive of diversity, some have made specific documents related to their programs available. The University of Michigan at Ann Arbor has released two parts of its diversity document entitled "Points of Intersection." The Ann Arbor program includes staff education and a full-time diversity librarian, as well as a task force on diversity. "Points of Intersection" articulates a broad basis for academic libraries' contributions to a universitywide multicultural effort.

Many programs are described in more detail in the flyer on cultural diversity programs in ARL libraries. Examples include the creation of special positions, such as multicultural services librarian and cultural outreach librarian, at a number of universities; the establishment of committees or task forces at other universities; and the establishment of workshops to raise staff awareness and emphasize cross-cultural training. ${ }^{19}$

To summarize the main points made in the literature, in higher education as in business, attention is increasingly focusing on issues of diversity rather than on affirmative action. Although affirmative action programs remain one of the crucial paths by which institutions may increase their diversity, these programs are still a source of ambivalent feeling for some librarians. The mechanism for implementing affirmative action policies varies from institution to institution, as does the approach to diversity programming. In general, administrative support, systemic thinking, and low budget requirements characterize successful programs.

\section{AFFIRMATIVE ACTION AND DIVERSITY AT IOWA STATE UNIVERSITY LIBRARY}

The affirmative action or diversity program at Iowa State University Library has a number of components. It is based on a firm commitment to diversify the university's faculty, which is seen in ongoing recruitment and staff development programs. Some specific examples include recruitment trips to library school campuses, educational and awareness sessions with staff, and meetings of the university's Steering Committee on Diversity. The library also participates in the university's larger diversity program. For example, the school has a special funding program, administered by the university provost, that supports hiring minorities in targeted areas. Additionally, the university has had an Affirmative Action Committee, now called the Library Committee on Diversity, since the late 1970s. Its longevity makes it somewhat different from similar committees at other institutions, and gives the library the opportunity to look at what has and has not worked well over time. What follows is a description of its evolution.

\section{THE AFFIRMATIVE ACTION COMMITTEE}

The Library Affirmative Action Committee was created by the dean in 1977 in response to a call for each large unit on campus to have such a committee. Initially, these committees were part of a universitywide Affirmative Action Council. When the council ceased to meet, the unitlevel committees across the campus were 
largely phased out. The exception to this was the library group. The committee consisted of faculty librarians and paraprofessional staff.

The main responsibility of the committee was to work with library faculty search committees. A representative from the Library Affirmative Action Committee was appointed to each search committee as an ex officio member. The representative's tasks were:

- to provide each member of the search committee with basic information about equal opportunity employment and affirmative action;

- to monitor search committee activities for fairness in terms of equal opportunity law;

- to encourage consideration of candidates protected under affirmative action guidelines;

- to hold exit interviews with candidates; and

- to report in writing to the dean of library services at the conclusion of each search.

The desire that the interview process be fair for each candidate comes through clearly in reporting letters, in memos distributed to search committee members, and in librarywide memos.

These tasks were sometimes uncomfortable for the representative and the search committee members, but over time fewer illegal or inappropriate questions were asked. Affirmative action representatives learned to handle illegal questions in a number of ways, such as rephrasing questions, telling candidates they did not have to answer illegal questions, and talking privately with colleagues who asked unacceptable questions. As a result of education by the Affirmative Action Committee and the library administration, adoption of standard interview procedures, and changes in societal attitudes as a whole, the incidence of illegal questions in interviews at the university's library seems fairly low today.

A fault of the committee was that its members essentially became enforcing agents, acting more reactively than proactively, because the committee was focused solely on the search process. The committee was fairly limited in its outreach to the library staff as a community. The committee members thought that they should continue to monitor individual searches, but that a broader focus was needed in order to become more effective. The committee needed to move away from being a regulatory committee and toward being an educational committee without abandoning its responsibility to equal employment opportunity and affirmative action in the library.

The committee began looking at this possibility in 1990, the year the university's new dean of library services began examining all existing committees within the library to see how the library's work was structured and how it might better be accomplished. This was a good opportunity for the committee to identify what goals it held in common as a group and with the library administration, and whether there might be some alternative ways to accomplish those goals that had not been pursued previously.

\section{Building strong programs requires a good understanding of diversity issues, an overall strategy, support from all levels of the organization, and the ability to deal with funding limitations.}

The committee's goals were revised to reflect the general shift, identified in the literature, from a focus in higher education on affirmative action to a focus on broader issues of diversity. The result has been a revitalization of the committee's role on search committees and a strong emphasis on staff education for diversity. One reflection of this shift in emphasis was the changing of the committee's name to the Library Committee on Diversity. Also, the committee's documents and manual have been completely revised (see appendix). The "Points of Intersection" documents from the University of Michigan were used in the revision process.

The committee is still comprised of professional and paraprofessional staff. 
This was appropriate under its former charge because paraprofessional staff sit on some search committees and have the opportunity to meet with candidates and provide feedback. The new makeup of the new committee is an even greater advantage because it extends educational efforts toward all staff members. In the spring of 1991, a workshop was offered to supervisors of paraprofessional staff, and one member of the committee participated in the creation of a manual for those who supervise students. Also, Search Committee information packets have been revised, and the committee and the dean now share responsibility for emphasizing equal opportunity and affirmative action to faculty search committees. The dean addresses those issues with the Search Committee in the initial meeting, and a representative from the Committee on Diversity maintains a focus on these issues throughout the search process.

Training materials and programs for library staff members have been developed and continue to evolve as the committee learns more about diversity issues. Committee members, for instance, have become more aware of the wide spectrum of views about diversity, with all the shadings of opinion possible being held by one or another members of the staff. They, also, have learned more about trainingwhat works and what does not workfrom experience, from the literature, and by having one member of the committee receive training from an external consulting firm specializing in diversity issues. Self-education as well as education for other library staff continues to be a part of the committee's responsibility.

Having reformulated its charge and refocused its energies, the committee had a number of questions about the environment within which the librarians would be working. Were the proposed changes appropriate? Were they useful? Would they meet library needs? To answer these questions, the committee revised a survey of staff attitudes and perceived training needs regarding equal employment opportunity and affirmative action that had been used by the Affirmative Action Committee during its first year. The survey was administered to the entire library staff. The goal was to take the temperature of the library's environment and assess staff need for more information about equal employment opportunity and affirmative action, broadly conceived, in the library.

The questionnaire return rate of 55 percent gave a statistically unrepresentative sample. However, the broad range of opinions expressed by the respondents was, and continues to be, helpful in evaluating the program. The implications of the results lie mainly in the area of education.

Diversity issues are difficult ones for many people. Staff members with concerns need a safe, constructive forum within which to work on these issues both intellectually and emotionally. Individual, informal contacts provide one such forum. Some staff may need the presence of a committee member to stay within bounds when interviewing candidates. This is because they are either new and unaware of the legal boundaries or of the university library's seriousness in adhering to them, or because they are uncomfortable with equal employment opportunity and affirmative action guidelines and have resisted past education. Many staff are openly interested in issues of diversity and want to know more.

The results support the need for continuing education, the usefulness of an active voice supporting affirmative action programs, and the value of diversity among the staff. The results underline the need for librarians to keep working at improving the environment within which they work. In discussing their staff education workshop program, the Ann Arbor Graduate Library's documents concur with the authors' finding for the need for ongoing education. The documents state:

To have the concept of diversity truly take hold, the education process must be an ongoing one. Awareness, enlightenment, and the ability to practice what is learned in a safe environment-supportive of questioning and vulnerabilitymust be available to all. This is essential to any diversity effort and most directly 
confronts both individual and institutional discrimination. ${ }^{20}$

\section{CONCLUSIONS}

In his discussion of the role of campuswide affirmative action committees, Daniel C. O'Rourke suggests that "... committees can be most effective in helping accomplish organizational goals including affirmative action (AA) and nondiscrimination goals (perhaps the most effective resource)." ${ }^{21}$ His experience is that the existence of such a committee helps to focus campus attention on affirmative action, and can motivate the affirmative action officer by sharing the work, supporting affirmative action goals, keeping affirmative action activity broad, identifying new issues, and finding new approaches to old issues. ${ }^{2}$ In addition, the authors have found the benefits in having such a committee in the library to include contributing to the creation of an affirming environment, increasing awareness and knowledge about equal employment opportunity and affirmative action among the library staff, assuring a goodwill effort is made in recruiting minorities and women, adding credibility to the recruitment process in the eyes of library staff, and helping to ensure legal compliance with appropriate laws and guidelines.

The authors' experience backs up Glaviano and Lam's observation that a library doesn't need a big budget to provide local programs; Iowa State University Library has no separate budget. Glaviano and Lam also point out the importance of continuous support by the library administration for the development of cultural diversity programming, another conclusion with which the authors concur. ${ }^{23}$

O'Rourke's final advice about affirmative action committees is a good reminder to those already engaged in this kind of endeavor, as well as those who are just beginning:

Be patient. Effective affirmative action committees and programs will not spring up overnight. It may take years. Work at it, work with it, and be content with incremental gains. The committee will grow more effective step by step..$^{24}$

\section{REFERENCES}

1. College \& Research Libraries News 52(July/Aug. 1991):446.

2. Elizabeth Dickinson and Margaret Myers, "Affirmative Action and American Librarianship," in Michael H. Harris, ed., Advances in Librarianship (New York: Academic Pr., 1978), 121.

3. Ibid.

4. Cliff Glaviano and R. Errol Lam, "Academic Libraries and Affirmative Action: Approaching Cultural Diversity in the 1990s," College \& Research Libraries 51(Nov. 1990): 517.

5. Ibid., 516 .

6. Ibid., 517 .

7. Ibid., 518.

8. ACRL Task Force on Recruitment of Underrepresented Minorities, Recruiting the Underrepresented to Academic Libraries," College \& Research Libraries News 51(Dec. 1990): 1018.

9. "Racial and Ethnic Diversity Resolution Adopted," College \& Research Libraries News 52(June 1991): 380.

10. "ACRL Acts on Minority Recruitment Report," College \& Research Libraries News 51(Dec. 1990): 1028.

11. Association of Research Libraries, Affirmative Action Policies and Practices in ARL Libraries (Spec Kit 163), (Washington, D.C.: Office of Management Services, Association of Research Libraries, 1990), introductory page.

12. Association of Research Libraries, Cultural Diversity Programming in ARL Libraries (SPEC Kit 165) (Washington, D.C.: Office of Management Services, Assn. of Research Libraries, 1990), introductory page.

13. Ibid.

14. Patrick A. Hall, "Against Our Best Interests: An Ambivalent View of Affirmative Action," American Libraries 22(Oct. 1991): 898-902. 
15. Roberto G. Trujillo and David C. Weber, "Academic Library Responses to Cultural Diversity: A Position Paper for the 1990s," Journal of Academic Librarianship 17July 1991): 158.

16. Ibid., 157.

17. Ibid., 161 .

18. Jeanne M. K. Boydston, "Hiring Practices, Equal Employment Opportunity and Affirmative Action in ARL Libraries," Journal of Library Administration 14, no.4(1991): 22.

19. Association of Research Libraries, Cultural Diversity Programming in ARL Libraries.

20. Points of Intersection II (Ann Arbor, Mich.: University of Michigan Library, 1990), 9.

21. Daniel C. O'Rourke, "Campus Affirmative Action Committees: A Practical Look at Identifying the Problem and Finding a Solution," CUPA Journal 40, no.3(Fall 1989): 48.

22. Ibid., 49.

23. Glaviano and Lam, 519.

24. O'Rourke, 50.

\section{APPENDIX \\ COMMITTEE DOCUMENTS \\ COMMITTEE ON DIVERSITY}

\section{Purpose}

The Committee exists to support the commitment of the library to equal opportunity and affirmative action by providing formal education, by assisting library staff in the hiring process, and by serving as an informal resource.

\section{Mission and Responsibility}

The Library Committee on Diversity works with the Dean/Department Executive Officer (DEO) to develop and promote a diverse work force within the ISU Library. The creation and maintenance of a community of women and men that is multicultural, multiracial, multinational and respectful of the dignity of all persons are essential to the educational mission of this library. The Committee's role is:

- To maintain a focus on equal employment opportunity and affirmative action within the Library.

- To inform and educate Library personnel concerning equal employment opportunity and affirmative action.

- To help create a work environment in which all personnel are able to develop to the fullest extent of their potential.

- To assist selection committees in the recruitment of members of protected classes for professional positions, and to serve as a resource for those who hire support staff.

\section{Organization}

- The Committee will consist of not more than six members who will be appointed by the Dean to two-year terms, and may be reappointed once. Members will not ordinarily be reappointed for more than four consecutive years.

- The Committee selects its own Chair subject to approval of the Dean of Library Services. The Chair will serve a term of one year and may be selected to serve up to four successive terms.

- The Committee will be responsible to and report as needed through its Chair to the Dean/DEO.

- The Chair will recruit new members for the Committee, with recommendations of the Committee, as current members resign. Vacancies should be filled as soon as possible.

- Meetings of the Committee will be called as needed by the Chair, the membership of the Committee, or the Dean of Library Services. Brief minutes of each meeting will be 
routed to members. A permanent file of most recent Committee papers will be in the custody of the Chair, with older materials placed in the Archives collection.

\section{ROLE ON SELECTION COMMITTEES}

- The Committee will designate a Committee on Diversity member to serve as a non-voting member on each selection committee. Committee on Diversity members will not represent the Committee on selection committees for positions within their own departments.

- The Committee representative will serve as a resource and advocate for equal opportunity and affirmative action issues, providing the search committee with pertinent background information and helping the group to understand and follow the Library's commitment to equal opportunity and affirmative action. The representative will speak to issues relevant to equal opportunity/affirmative action in the search process and bring to the attention of the chair of the search committee, when necessary, activities which infringe upon established policy. (See checklist below)

- The Committee will distribute packets of affirmative action information to search committee members at or before the first meeting of the search committee.

- In an effort to assist the Library in better effecting the principles of equal employment opportunity, the Committee representative is provided a fifteen-minute period at the end of the agenda with each candidate.

- The Committee representative will provide a written report to the Dean following each search, indicating whether or not equal opportunity and affirmative action guidelines were followed. Any concerns related to equal opportunity or affirmative action in a particular search are also addressed in this report.

\section{GUIDELINES FOR THE COMMITTEE ON DIVERSITY REPRESENTATIVE ON A SELECTION COMMITTEE}

\section{Search Committee Responsibilities}

- Contact chair of search committee.

- Get copies of EEO/AA information packet (Library Administration Office will make copies; Chair keeps original on file).

- Distribute information packets at first meeting of search committee, when possible, after Dean has spoken on AA.

- Explain role of Committee representative to the search committee.

- Advocate casting a wide net.

- Advocate particular attention to Affirmative Action candidates as appropriate throughout the search process.

- Attend all committee meetings; arrange for substitutes as necessary.

- Maintain a file with all documents relevant to search.

- Submit written report to Dean of Library Services, copy to Committee on Diversity file.

\section{Campus Interviews}

- Attend search committee meetings (including lunches with the committee) with each candidate. Attend all open library meetings (formal and informal) for each candidate.

- Conduct an exit interview with each candidate.

\section{Meetings Not Attended As Committee Representative}

- One-on-one telephone calls to references.

- Dinners.

- Nonsearch committee meetings with candidate (section meetings, Administrative Council meetings, etc.).

- One-on-one meetings.

- Receptions. 